\title{
EARLY TRIASSIC POSTCRANIAL TEMNOSPONDYL REMAINS FROM SOUTHERN BRAZIL (SANGA DO CABRAL FORMATION, PARANÁ BASIN)
}

\author{
SÉRGIO DIAS-DA-SILVA \\ Centro de Ciências Rurais, Universidade Federal do Pampa, Campus de São Gabriel, Av. Antônio Mercado, Bairro \\ São Clemente, 97300-000, São Gabriel, RS, Brazil.sergiosilva@unipampa.edu.br \\ CESAR LEANDRO SCHULTZ \\ Departamento de Paleontologia e Estratigrafia, Instituto de Geociências, UFRGS, Av. Bento Gonçalves, 9500, \\ 91540-000, Porto Alegre, RS, Brazil.cesar.schultz@ufrgs.br
}

\begin{abstract}
Postcranial temnospondyl remains have been, as a general trend, neglected by paleontologists. In South America, most published temnospondyl material generally consists of cranial elements, excepting for brachyopoid postcranial material from Argentina. This work provides the first survey of temnospondyl postcranial bones recovered from the south Brazilian Lower Triassic Sanga do Cabral Formation. The reduced ossification of the bones, among other characters, point to the presence of aquatic temnospondyls in this unit. As the highly fragmentary nature of most materials constrains an accurate taxonomic identification, some of them are assigned to Temnospondyli insertae sedis. Other bones, however, display a morphology which is consistent with well-described aquatic Mesozoic stereospondyls. This preliminary assessment on temnospondyl postcranial skeleton could be an important contribution for future comparative research in order to increase our knowledge about this interesting group of basal tetrapods, which achieved a worldwide distribution during the Mesozoic. In the absence of cranial elements, postcranial features can be very useful in the identification of temnospondyl remains and investigation on this topic should be encouraged.
\end{abstract}

Key words: Temnospondyli, Stereospondyli, postcranial skeleton, Lower Triassic, Paraná Basin.

RESUMO - Restos pós-cranianos de temnospôndilos tem sido, via de regra, negligenciados pelos paleontólogos. Na América do Sul, a maioria dos trabalhos publicados sobre esse grupo geralmente consistem de elementos cranianos, excetuando materiais pós-cranianos de braquiopóides da Argentina. Este trabalho fornece o primeiro levantamento de ossos pós-cranianos de temnospôndilos provenientes da Formação Sanga do Cabral (Triássico Inferior brasileiro). A ossificação reduzida dos ossos, entre outros características, evidencia a presença de temnospôndilos aquáticos nesta unidade. Uma vez que a natureza fragmentária da maioria dos materiais impede uma identificação taxonômica mais exata desses materiais, alguns deles são identificados como Temnospondyli insertae sedis. Outros ossos, contudo, apresentam uma morfologia consistente com formas já descritas de estereospôndilos aquáticos mesozóicos. Este estudo preliminar de restos pós-cranianos é uma importante contribuição para futura pesquisa comparativa, na intenção de aumentar nosso conhecimento acerca deste interessante grupo de tetrapods basais que atingiu distribuição mundial durante o Mesozóico. $\mathrm{Na}$ ausência de elementos craniais, características pós-craniais podem ser muito úteis na identificação de restos de Temnospôndilos e as investigações neste assunto devem ser encorajadas.

Palavras-chave: Temnospondyli, Stereospondyli, esqueleto pós-craniano, Triássico Inferior, bacia do Paraná.

\section{INTRODUCTION}

The short temporal distribution of most temnospondyls has led several authors to claim them as useful biostratigraphic markers (Cosgriff, 1969, 1984; Anderson \& Cruickshank, 1978; Kitching, 1978; Shishkin, 1994; Groenewald \& Kitching, 1995). In fact, they are among the commonest tetrapods in continental deposits during the Triassic. Moreover, the characteristic pattern of ornamentation found in the dermal bones of stereospondyls makes their identification (at least in a more inclusive level) easier than in other groups (Schoch \& Milner, 2000). Most South American stereospondyls exhumed in Triassic and Permo-Triassic units consist of cranial remains (Lavina \& Barberena, 1985; Marsicano, 1999, 2005; Marsicano et al., 2000; Dias-da-Silva et al., 2005, 2006a,b; Dias-da-Silva \& Marsicano, 2006; Piñeiro et al., 2007a, b, c), whereas postcranial materials are rare excepting for an almost complete postcranial skeleton of a 
brachyopoid from the Upper Triassic of Argentina (Rusconi, 1951; Marsicano, 1993). According to Warren \& Snell (1991), early paleontologists frequently left temnospondyl postcranial materials in the field, collecting and describing only cranial remains. This situation generated a great deal of information regarding cranial material and, as a result, axial and appendicular elements remained largely underestimated. The best known exceptions are the contributions by Watson (1917, 1919, 1926), Nilsson (1937), Bystrow \& Efremov (1940), Romer (1947), Cosgriff (1974), Warren \& Hutchinson (1983), Warren \& Snell (1991), Schoch \& Milner (2000), Dias \& Schultz (2003), and Pawley \& Warren (2005). Intense collecting, particularly in Lower Triassic levels of the Paraná Basin in the last years, has produced hundreds of cranial stereospondyl remains (mostly represented by dermal skull fragments), whereas clearly identifiable postcranial bones attributed to this group are fewer than fifty pieces, all of them undescribed. Therefore, it is reasonable to assume that differential preservation of postcranial bones compared to cranial remains could be due to taphonomic processes instead of collecting bias.

The aim of this short paper was to provide the first comprehensive survey of temnospondyl postcranial remains recovered from the Sanga do Cabral Formation, Lower Triassic of the Paraná Basin, southern Brazil.

\section{GEOLOGICAL SETTING}

The Lower Triassic Sanga do Cabral Formation crops out in southern Brazil, and it is a 50- to100-m thick unit that uncomformably covers the Guadalupian ("Middle Permian") Rio do Rasto (Langer, 2000; Malabarba et al., 2003; Cisneros et al., 2005) and the Permo-Triassic Pirambóia formations (Andreis et al., 1980; Scherer et al., 2000). According to Andreis et al. (1996), this unit also occurs in Uruguay, where the deposits are locally included in the Buena Vista Formation. However, according to Piñeiro et al. (2003, 2004, 2007a, b, c), the presence of varanopid pelicosaurs, basal procolophonids and nonstereospondyl temnospondyls provide evidence for the inclusion of the Buena Vista Formation close to the PermoTriassic boundary. Moreover, and according to Piñeiro et al. (2007c), the faunal content of the Colonia Orosco Local Fauna (Buena Vista Formation) appears to represent early stages of the turnover evidenced in the communities of continental tetrapods at the Permo-Triassic Boundary. Recently, Dias-da-Silva et al. (2006b) questioned the presence of Permian strata in the Buena Vista Formation, arguing that the varanopid material was probably misidentified, and also because owenettid procolophonids range from Upper Permian to Lower Triassic. More recently, however, new data published by Piñeiro et al. (2007c) and a careful reading of the descriptions of Uruguayan temnospondyls provided arguments to convince the present authors that the Buena Vista Formation is likely Permo-Triassic in age as previously stated. Therefore, the Sanga do Cabral Formation is younger than the Uruguayan unit because the faunal components of Sanga do Cabral Formation occur in Lower Triassic deposits worldwide (e.g., through the presence of Procolophon, thrinaxodontid cynodonts, a rhytidosteid stereospondyl, a single protorosaurid vertebra, and a doubtful lystrosaurid stapes; see Langer \& Schultz, 1997; Langer \& Lavina, 2000; Cisneros \& Schultz, 2002; Abdala et al., 2002; Dias-daSilva et al., 2006a,b). The Sanga do Cabral Formation consists of massive to trough cross-bedded intraformational conglomerates and horizontally bedded sandstones which are interpreted as deposited by braided river systems with poorly confined channels that were developed on a low gradient alluvial plain. The presence of argillaceous lenses in the sequence provides evidence of lakes and ponds related to the alluvial plains (Zerfass et al., 2003). The bone-bearing levels correspond to intraformational conglomerates that provided mostly disarticulated and fragmented vertebrate remains. Hence, both the sedimentology of the unit and some taphonomic features of the vertebrates collected (scattered, disarticulated, fragmented, etc.) suggest that intense reworking took place during the deposition of these bonebearing levels.

Preservation of tetrapods in the neighboring Buena Vista Formation from Uruguay is quite similar. This unit is also characterized by reddish fine sandstones interbedded with lenticular clay layers and bone-bearing intraformational conglomerates (Bossi \& Navarro, 1991; Goso et al., 2001; Piñeiro et al., 2003).

Table 1. Temnospondyl postcranial elements from Sanga do Cabral Formation.

\begin{tabular}{l|l}
\hline \multicolumn{1}{c|}{ Specimen } & \multicolumn{1}{c}{ Osteological identification } \\
\cline { 1 - 1 } UFRGS PV0326T & $\begin{array}{l}\text { Distal fragment of a femur } \\
\text { A complete left stereospondyl } \\
\text { humerus }\end{array}$ \\
\cline { 1 - 1 } UFRGS PV0331T & Distal fragments of humeri \\
\cline { 1 - 1 } UFRGS PV0332T; & Distal fragments of femora \\
UFRGS PV0339T & Proximal fragment of a femur \\
UFRGS PV0353T; & A cleithrum \\
UFRGS PV0375T & A complete right stereospondyl iliur \\
UFRG PV0369T & Radial fragments \\
UFRGS PV0387T & \\
UFRGS PV0499T & \\
UFRGS PV0357T; & \\
UFRGS PV0358T & \\
UFRGS PV0236T to UFRGS & \\
PV0238T; UFRGS PV0253T; & \\
UFRGS PV0255T to UFRGS & \\
PV0258T; UFRGS PV0330T; & \\
UFRGS PV0333T to UFRGS & \\
PV0338T; UFRGS PV0362T to & \\
UFRGS PV0365T; UFRGS & \\
PV0386T; UFRGS PV0402T; & \\
UFRGS PV0351T to UFRGS & \\
PV0352T; UFRGS PV0354T to & \\
UFRGS PV0355T; & \\
UFRGS PV0359T; UFRGS & \\
PV0370T to UFRGS PV0374T; & \\
UFRGS PV0376T & \\
\hline
\end{tabular}




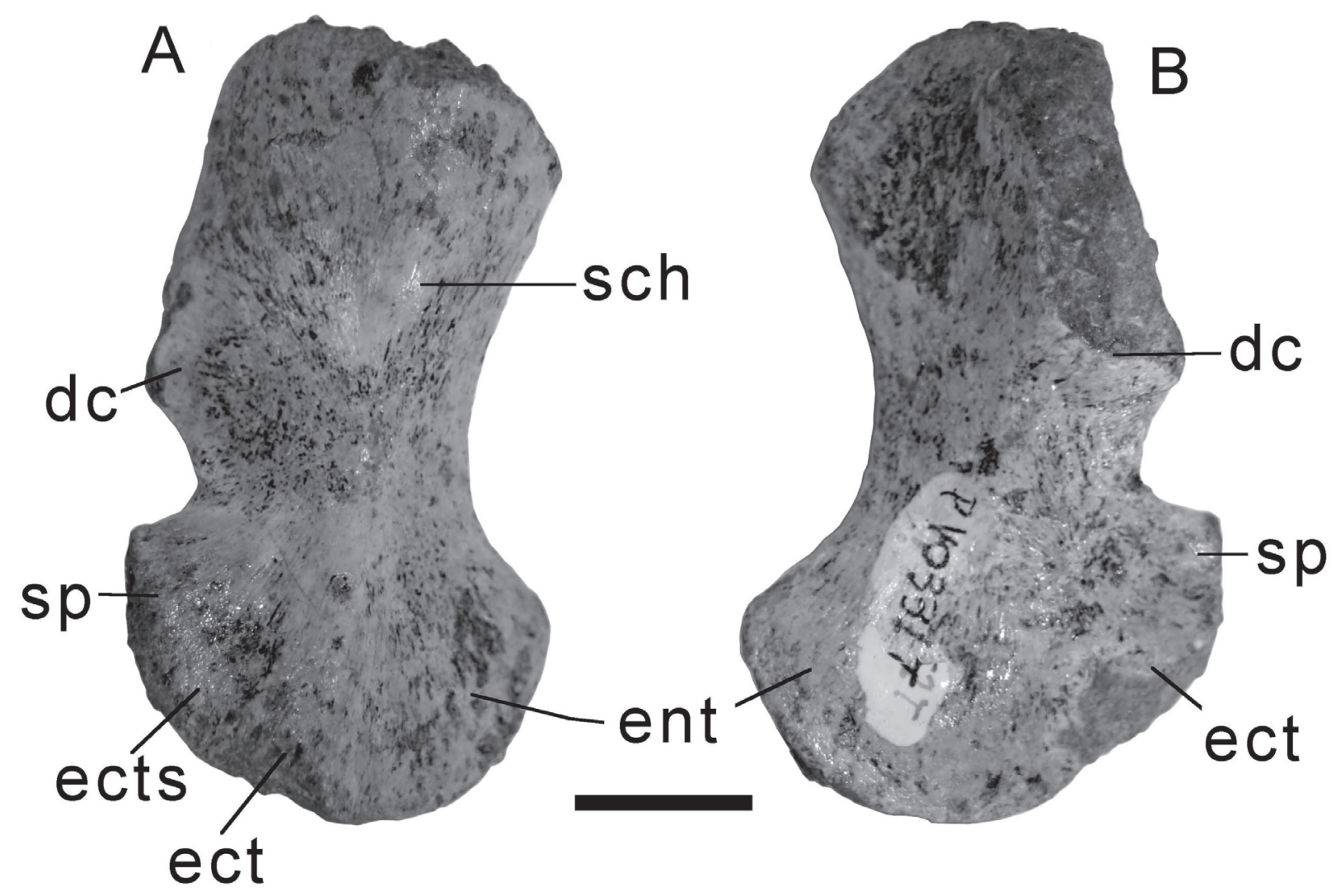

Figure 1. UFRGS PV $0331 \mathrm{~T}$, a stereospondyl left humerus in dorsal (A) and ventral (B) views. Abbreviations: dc, deltoid crest; ect, ectepicondyle; ects, ectepicondylar sulcus; ent, entepicondyle; sch, attachment of scapulo-humeralis anterior muscle; sp, supinator process. Scale bar $=10 \mathrm{~mm}$.

\section{MATERIALS AND METHODS}

The described material is housed in the fossil collection of the Universidade Federal do Rio Grande do Sul (UFRGS), in Porto Alegre. Several remains tentatively assigned to appendicular elements of temnospondyls were examined during the present study and a complete list can be accessed in Table 1. From the materials listed in this Table, those better preserved that could be helpful for taxonomic identification are herein described: a left humerus (UFRGS PV0331T), a right ilium (UFRGS PV0499T), a cleithrum(UFRGS PV0387T), two radial fragments (UFRGS PV0357T and UFRGS PV0358T), and finally, two femoral fragments (UFRGS PV0369T and UFRGS PV0326T).

All specimens were recovered on different field trips to outcrops in several localities from the central region (central depression) of the state of Rio Grande do Sul (see Dias-daSilva et al., 2006a:fig. 1). They were found scattered and isolated, and therefore, none can be linked to the same individual. For the same reason, it is difficult to directly ascribe them to any already known taxon, since they were erected mainly based on cranial morphology.

The specimens UFRGS PV0331T, UFRGS PV0499T, and UFRGS PV0387T (humerus, ilium and cleithrum, respectively) are well preserved and most features can easily be observed. The remaining postcranial elements are broken fragments, and consequently, they provide limited information when compared with the well-preserved ones. All elements were found already detached from rocks and no laboratory preparation was necessary.

\section{DESCRIPTION}

UFRGS PV0331T. This left humerus (Figure 1) is relatively short and slightly dorsoventrally compressed. The proximal and distal ends are expanded and separated by a short diaphysis, and are twisted at an angle of approximately 60 degrees. In dorsal view, the distal extremity is more expanded than the proximal one and its articular surface is slightly curved and continuous. The supinator process, ectepicondylar sulcus (misinterpreted as an entepicondylar sulcus by Santana, 1992), ectepicondyle, and entepicondyle are poorly developed. The entepicondylar foramen is not present as in all stereospondyls (Schoch \& Milner, 2000; Yates \& Warren, 2000). On the anterior border of the proximal extremity, a tubercle for muscular insertion is present, probably for the attachment of the scapulo-humeralis anterior muscle. In ventral view a well-developed deltoid crest is present.

Remarks. Santana (1992) compared the material with the humerus of the mastodonsaurid Parotosuchus pronus, and she found them to be very similar. However, as similar humeri were already known for rhytidosteids, trematosaurids and 


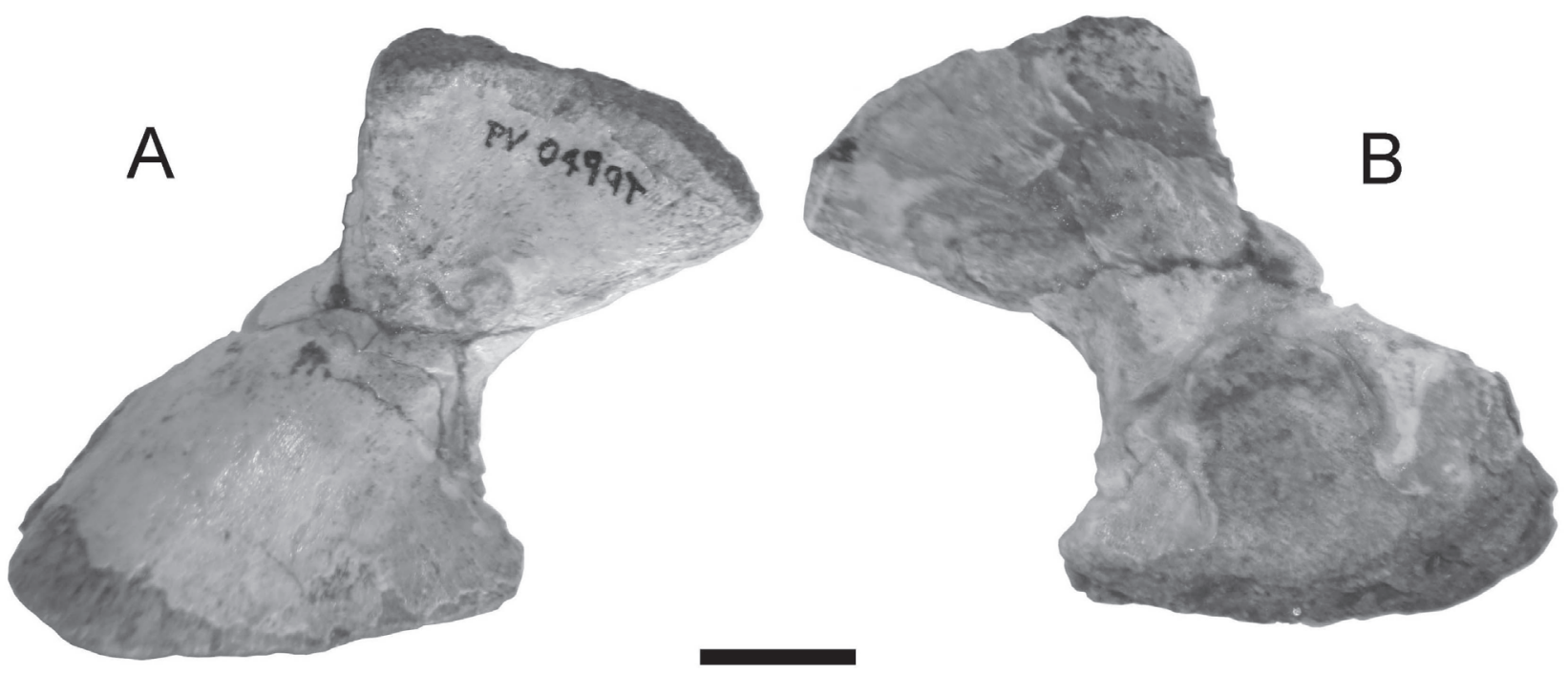

Figure 2. UFRGS PV0499T, a stereospondyl right ilium in medial $(\mathbf{A})$ and lateral $(\mathbf{B})$ views. Scale bar $=10 \mathrm{~mm}$.

mastodonsaurids, Santana (1992) assigned the Brazilian material to Temnospondyli incertae sedis. Nonetheless, the loss of the entepicondylar foramen in UFRGS PV0331T clearly relate it to Stereospondyli, as this condition is considered a diagnostic character of that group (Schoch \& Milner, 2000). Additionally, the presence of an angle of less than 90 degrees between the two ends, an adaptation to an aquatic habit, is found in all non-terrestrial stereospondyls (Warren \& Snell, 1991; Schoch \& Milner, 2000). Moreover, according to several authors (Warren \& Snell, 1991; Schoch \& Milner, 2000; Pawley \& Warren, 2005), stereospondyls with weakly developed processes for muscle attachment and poorly ossified articulation surfaces, as occur in UFRGS PV0331T, were likely to have been primarily aquatic animals.

UFRGS PV0499T. Right ilium (Figure 2). It is a slender bone with an anteroposteriorly expanded dorsal blade. Its distal end, also anteroposteriorly expanded, bears the dorsal part of the acetabulum. It is slightly sigmoid in anterior and posterior views and posteriorly inclined.

Remarks. Ilium structure is very conservative among stereospondyls, as also occurs with the humeri. Thus, it is not useful for taxonomic purposes. For example, UFRGS PV0499T is quite similar to those attributed to the putative rhytidosteid Acerastea (Warren \& Hutchinson, 1987:fig. 12), but this morphology is also comparable to that described for the mastodonsaurid Parotosuchus (Warren \& Snell, 1991: fig. 9). The only exception is the ilium of the metoposaurids, in which the dorsal blade is unexpanded anteroposteriorly and massive in cross section (see Warren \& Hutchinson, 1987; Warren \& Snell, 1991). Thus, as previously mentioned for the humerus UFRGS PV0331T, the described ilium cannot be assigned to any taxonomic level more specific than Stereospondyli.

UFRGS PV0387T. UFRGS PV0387T (Figure 3) is a nearly complete cleithrum which is a triangular rod in cross section that possesses an expanded head and pointed tail with facets for articulation with the scapulocoracoid and clavicle. The tip of the tail is broken, but it is reasonable to assume that at least two thirds of its extension is preserved. The posteroventral portion of the head is also fractured and it is subdivided into two flanges unequally developed, one following the line of the external surface of the head and

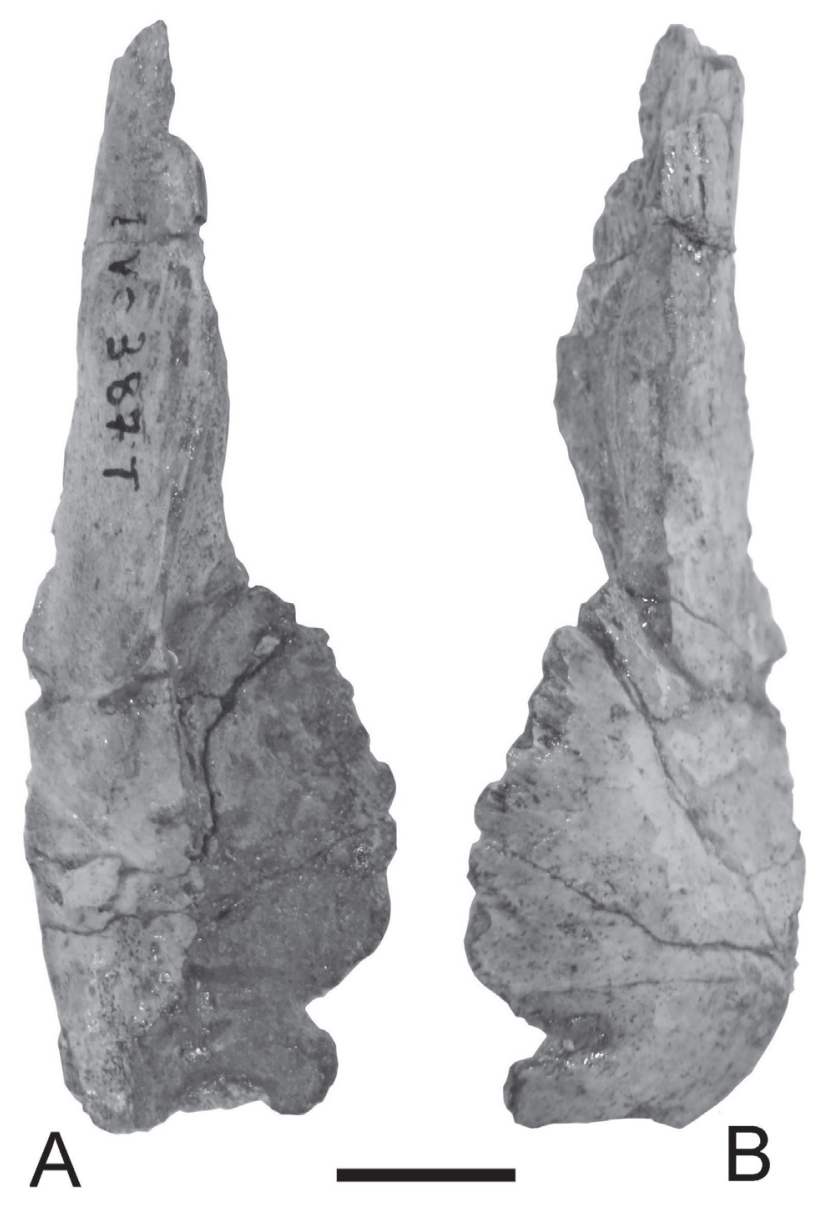

Figure 3. UFRGS PV0387T, a cleithrum in medial (A) and lateral (B) views. Scale bar $=10 \mathrm{~mm}$ 

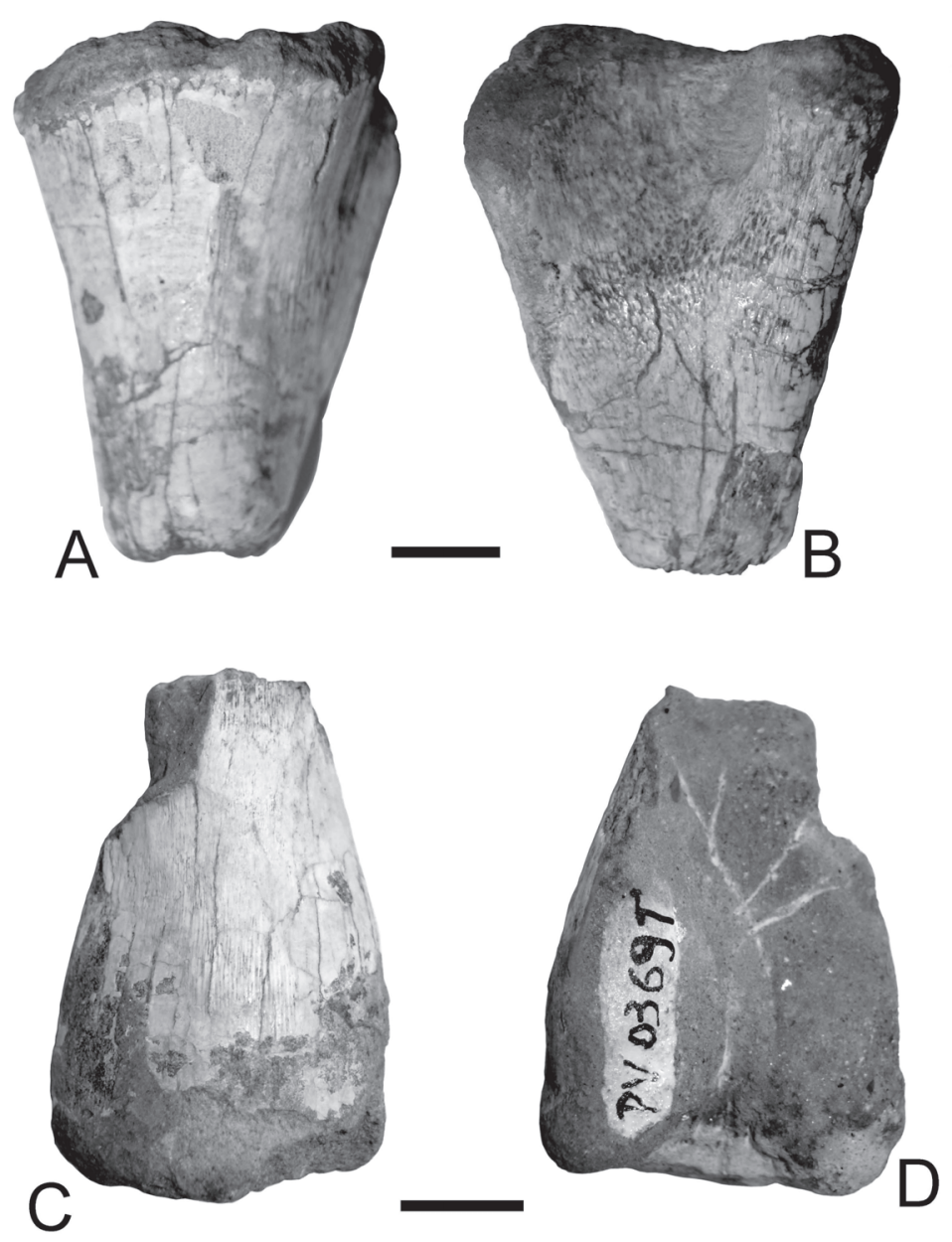
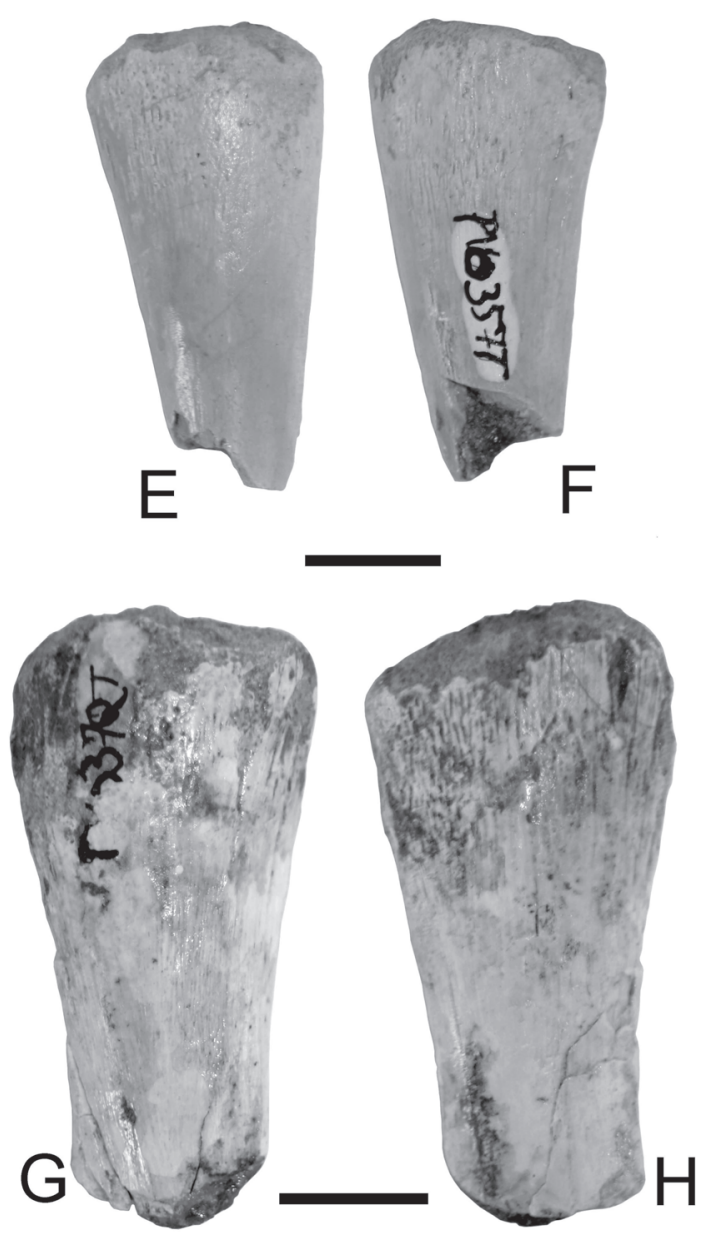

Figure 4. Appendicular elements: UFRGS PV0369T, a proximal femoral fragment in dorsal (A) and ventral (B) views; UFRGS PV0326T, distal femoral fragment in dorsal (C) and ventral (D) views; UFRGS PV0358T, a proximal radial fragment in dorsal $(\mathbf{E})$ and ventral $(\mathbf{F})$ views; UFRGS PV0372T, a proximal radial fragment in dorsal $(\mathbf{G})$ and ventral $(\mathbf{H})$ views. Scale bar $=10 \mathrm{~mm}$.

other continuous with its inner surface along with the ridge that delineates the scapulocoracoid articular area and the clavicular articulation area (lamina suprascapularis sensu Bystrow \& Efremov (1940). The recess of both flanges holds the anterodorsal part of the scapula.

Remarks. UFRGS PV0387T resembles cleithra present in Triassic stereospondyls such as Bentosuchus sushkini (Bystrow \& Efremov, 1940), Parotosuchus pronus (Howie, 1970). However, the lack of distinctive cleithral characters among different temnospondyls constrains a more accurate identification. In the comprehensive study of stereospondyls, Schoch \& Milner (2000) affirm that the cleithrum is only known in a few species, and appears to be quite conservative throughout the group. Therefore, UFRGS PV0387T is assigned to Stereospondyli incertae sedis, mainly due to biostratigraphic reasons, since most non-stereospondyl temnospondyls did not survive the Permo-Triassic mass extinction.

UFRGS PV0369T. Proximal femoral fragment (Figure 4A, B). This material is badly preserved in ventral view, where the periosteal layer of bone was lost. It will be discussed together with UFRGS PV0326T (see below).

UFRGS PV0326T. Distal femoral fragment (Figure 4C, D).
This fragment is bigger compared to UFRGS PV0369T, and indicating it belongs to a larger individual. The head for tibial and fibular articulation is slender and slightly bifurcated, and ventrally, the beginning of a poorly developed Y-shaped system of adductor ridge and trochanters can be observed.

Remarks. Warren \& Hutchinson (1983) pointed out that femoral elements of temnospondyls do not vary greatly within the group and differences occur mainly in the slenderness of the shaft and the degree of development of the ventral adductor crest and the internal trochanter. Warren \& Snell (1991) could not find differences to define femoral patterns among different families. Hence, UFRGS PV0326T and UFRGS PV0369T are assigned to Temnospondyli incertae sedis.

UFRGS PV0358T and UFRGS PV0372T. Two proximal radial fragments (Figure 4E-H). UFRGS PV0372T is larger than UFRGS PV0358T and therefore belongs to a more robust or a more mature individual. Both ends are subcircular.

Remarks. According to Warren \& Snell (1991), few radial elements were described for Mesozoic temnospondyls, and therefore, ${ }_{2}$ any range of variation is unknown. Thus, these fragments cannot be assigned to any taxonomic level more specific than Temnospondyli. 


\section{DISCUSSION}

Excepting for the diagnostic humerus, ilium, and cleithrum, it is important to point out that the taxonomic assignment of the remaining fragments (Temnospondyli incertae sedis) is tentative and based on their large size when compared with the previously described basal amniotes recorded to FSC. Protorosaurids, procolophonids and non-mammalian cynodonts, and ?lystrosaurids from this unit belong to relatively smaller taxa. In other words, from the Lower Triassic, only temnospondyls are consistent (so far) with the size of the elements described here.

In spite of the small number of postcranial elements known from the Sanga do Cabral Formation, several identifiable specimens described here strongly suggest an aquatic mode of life. The humerus UFRGS PV0331T certainly presents anatomical features found in non-terrestrial stereospondyls (e.g., humeral twisting angle less than 90 degrees and poorly developed processes). Moreover, the slenderness and small degree of ossification present in the remaining materials (UFRGS PV0499T, UFRGS PV0387T, and UFRGS PV0357T) are consistent with those found in welldescribed Mesozoic postcranial skeletons of aquatic stereospondyls. Unfortunately, it is not possible to provide a less inclusive taxonomy for the material herein presented, since most temnospondyl taxa either did not preserve postcranial skeletons, or in such cases, the present postcranial elements do not provide informative characters due to the great deal of ecologic convergence. This situation produced, within temnospondyls, similar postcranial skeletons in different lineages (see ecomorphic discussion by Defaw, 1989). So far, the exceptions are the highly apomorphic postcranial skeletons of both metoposaurids (see Warren \& Snell, 1991), and the more terrestrial Lydekkerina huxleyi (Pawley \& Warren, 2005). The remaining fragments (UFRGS PV0358T, UFRGS PV0369T, UFRGS PV0326T and UFRGS PV0372T) are assigned to Temnospondyli incertae sedis, due to their lack of informative taxonomic features.

\section{CONCLUSION}

The purpose of the present contribution was to provide information about temnospondyl postcranial elements from the Sanga do Cabral Formation of southern Brazil. Previously, only cranial materials were described and published from that unit. Some of the specimens studied are assigned to Stereospondyli incertae sedis, although others are referred to Temnospondyli incertae sedis. It is important to point out that the lack of knowledge regarding postcranial temnospondyl remains should not be an obstacle in studying such materials. A good example of the usefulness of temnospondyl postcrania can be observed in the family Metoposauridae, where the wellknown skeleton possesses several autapomorphic characters that are useful for taxonomic purposes when cranial elements are absent. Unfortunately, apart from this family, our knowledge of postcranial elements is very scarce. Therefore, efforts to enhance information on this topic should be encouraged.

\section{ACKNOWLEDGMENTS}

The authors thank Conselho Nacional de Desenvolvimento Científico e Tecnológico for the financial support (grant 304068 / 2003-9 to SDS), and the Universidade Federal do Pampa for the facilities provided during this study. Claudia Marsicano and A. Warren critically reviewed an earlier version of this manuscript; and L. H. C. Vinadé provided English editing. Suggestions of G. Piñeiro and J. C. Cisneros greatly improved this paper.Finally, the senior author gives special thanks to Anne Warren for sending a cast of a cleithrum which was very helpful in the present study.

\section{REFERENCES}

Abdala, F.; Dias-da-Silva, S. \& Cisneros, J.C. 2002. First record of non-mammalian cynodonts (Therapsida) in the Sanga do Cabral Formation (Early Triassic) of Southern Brazil. Palaeontologia Africana, 38:92-97.

Ahlberg, P.E. 1991. A re-examination of sarcopterygian interrelationships, with special reference to the Porolepiformes. Zoological Journal of the Linnean Society, 103:241-287.

Anderson, J.M. \& Cruickshank, A.R.I. 1978. The biostratigraphy of the Permian and Triassic. A review of the classification and distribution of Permo-Triassic tetrapods. Palaeontologia Africana, 21:15-44.

Andreis, R.; Bossi, G.E. \& Montardo, D.K. 1980. O Grupo Rosário do Sul (Triássico) no Rio Grande do Sul. In: CONGRESSO BRASILEIRO DE GEOLOGIA, 31, 1980. Anais, SBG, São Paulo, 659-673 p.

Andreis, R.; Ferrando, L. \& Herbst, R. 1996. Terrenos carboníferos y pérmicos de la República Oriental del Uruguay. In: S. Archangelsky (ed.) El Sistema Pérmico en Argentina y Uruguay, Academia Nacional de Ciencias, p. 309-343.

Bossi, J. \& Navarro, R. 1991. Geología del Uruguay. Montevideo, Departamento de Publicaciones, Universidad de la República, $970 \mathrm{p}$.

Bystrow, A.P. \& Efremov, J.A. 1940. Benthosuchus sushkini Efremov, a labyrinthodont from the Eotriassic of Sharzhenga River. Trudy Paleontologicheskogo Instituta, 10:1-152.

Cisneros, J.C. \& Schultz, C.L. 2002. Procolophon brasiliensis n. sp., a new procolophonid reptile from the Lower Triassic of southern Brazil. Neues Jahrbuch für Geologie und Paläontologie Monatshefte, 2002:641-648.

Cisneros, J.C.; Abdala, F. \& Malabarba, M.C. 2005. Pareiasaurids from the Rio do Rasto Formation, southern Brazil: Biostratigraphic implications for Permian faunas of the Paraná Basin. Revista Brasileira de Paleontologia, 8(1):13-24.

Cosgriff, J.W. 1969. Blinasaurus, a brachyopid genus from Western Australia and New South Wales. Journal of the Royal Society of Western Australia, 52:65-88.

Cosgriff, J.W. 1974. Lower Triassic Temnospondyli of Tasmania. Special Paper - Geological Society of America, 149:1-134.

Cosgriff, J.W. 1984. The temnospondyl labyrinthodonts of the earliest Triassic. Journal of Vertebrate Paleontology, 4:30-46. 
Defauw, S.L. 1989. Temnospondyli Amphibians: A new perspective on the last phases in the evolution of the Labyrinthodontia. Michigan Academician, 21:7-32.

Dias, E.V. \& Schultz, C.L. 2003. The first paleozoic temnospondyl postcranial skeleton from South America. Revista Brasileira de Paleontologia, 6:29-42.

Dias-da-Silva, S.; Marsicano, C. \& Schultz, C.L. 2005. Early Triassic temnospondyl skull fragments from southern South America (Paraná Basin, Brazil). Revista Brasileira de Paleontologia, 8:165-172.

Dias-da-Silva, S. \& Marsicano, C. 2006. Sangaia, a replacement generic name for the rhytidosteid temnospondyl Cabralia, a preoccupied name. Journal of Vertebrate Paleontology, 26(4):1004.

Dias-da-Silva, S.; Marsicano, C. \& Schultz, C.L. 2006 a. Rhytidosteid Temnospondyls in Gondwana: A new taxon from the Lower Triassic of Brazil, Palaeontology, 49(2):381-390.

Dias-da-Silva, S.; Modesto, S.P. \& Schultz, C.L. 2006b. New material of Procolophon (Parareptilia: Procolophonoidea) from the Lower Triassic of Brazil, with remarks on the ages of the Sanga do Cabral and Buena Vista formations of South America. Canadian Journal of Earth Sciences, 43(11):16951693.

Goso, C.; Piñeiro, G.; De Santa Ana, H.; Rojas, A.; Verde, M. \& Alves, C. 2001. Caracterización estratigráfica de los depósitos continentales cuspidales neopérmicos (Formaciones Yaguarí y Buena Vista) en el borde oriental de la Cuenca Norte Uruguaya. In: CONGRESO LATINOAMERICANO DE GEOLOGÍA, 11, 2001. Actas, Montevideo, 18 p. (CDROM).

Groenewald, G.H. \& Kitching, J.W. 1995. Biostratigraphy of the Lystrosaurus Assemblage Zone. In: B. S. Rubidge, (ed.) Biostratigraphy of the Beaufort Group (Karoo Supergroup), Council for Geoscience, Geological Survey of South Africa, p. 35-39.

Howie, A.A. 1970. A new capitosauroid labyrinthodont from East Africa. Palaeontology, 13(2):210-253.

Kitching, J. W. 1978. The stratigraphic distribution and occurrence of South African fossil Amphibia in the Beaufort Beds. Palaeontologia Africana, 21:101-112.

Langer, M.C. 2000. The first record of dinocephalians in South America: Late Permian (Rio do Rasto Formation) of the Paraná Basin, Brazil. Neues Jahrbuch für Geologie und Paläontologie. Abhandlungen, 215:69-95.

Langer, M.C. \& Lavina, E.L. 2000. Os Amniotas do Neopermiano e Eotriássico da bacia do Paraná-répteis e "répteis Mamaliformes". In: M. Holz \& L.F. De Ros (eds.) Paleontologia do Rio Grande do Sul, UFRGS, p. 210-235.

Langer, M.C. \& Schultz, C.L. 1997. Further comments on the Brazilian Protorosaurs. Ameghiniana, 34(4):537.

Lavina, E.L. \& Barberena, M.C. 1985. Anfíbios ritidosteídeos e lidekkerinídeos da Formação Sanga do Cabral (Triássico Inferior do Rio Grande do Sul). Implicações bioestratigráficas e geocronológicas. Iheringia 10:19-27.

Malabarba, M.C.; Abdala, F.; Weiss, F.E.; Perez, P.A. 2003. New data on the late Permian vertebrate fauna of Posto Queimado, Rio do Rasto Formation, southern Brazil. Revista Brasileira de Paleontologia, 6:49-54.

Marsicano, C. 1993. Postcranial skeleton of a brachyopoid (Amphibia, Temnospondyli) from the Triassic of Mendoza (Argentina). Alcheringa, 17:185-197.

Marsicano, C. 1999. Chigutisaurid amphibians from the Upper
Triassic of Argentina and their phylogenetic relationships. Palaeontology, 42(3):545-565.

Marsicano, C. 2005. A new temnospondyl record from the Upper Triassic of Argentina. Ameghiniana, 42(2):501-504.

Marsicano, C., Perea, D. \& Ubilla, M. 2000. A new temnospondyl amphibian from the Lower Triassic of South America. Alcheringa, 24:119-123.

Nilsson, T. 1937. Ein Plagiosauridae aus dem Rhät Schonens. Beiträge zur Kenntnis der Organisation der Stegocephalengruppe Brachiopoidei. Acta Universitatis Lundensis, 35:1-39

Pawley, K. \& Warren, A. 2005. A terrestrial stereospondyl from the Lower Triassic of South Africa: the postcranial skeleton of Lydekkerina huxleyi (Amphibia: Temnospondyli). Palaeontology, 48(2):281-298.

Piñeiro, G.; Verde, M.; Ubilla, M. \& Ferigolo, J. 2003. First basal synapsids ("pelycosaurs") from South America, Late Permian?Early Triassic of Uruguay. Journal of Paleontology, 77:389392.

Piñeiro, G.; Rojas, A. \& Ubilla, M. 2004. A new procolophonoid (Reptilia: Parareptilia) from the Upper Permian of Uruguay. Journal of Vertebrate Paleontology, 24:814-821.

Piñeiro, G., Marsicano, C. \& Lorenzo, N. 2007a. A new Temnospondyl from the Permo-Triassic Buena Vista Formation of Uruguay. Palaeontology, 50(3):627-640.

Piñeiro, G.; Marsicano, C. \& Damiani, R. 2007b. Mastodonsaurid temnospondyls from the Upper Permian-Lower Triassic of Uruguay: the earliest record from South America. Acta Palaeontologica Polonica, 52(4):695-703.

Piñeiro, G.; Marsicano, C.; Goso, C. \& Morosi, E. 2007c. Temnospondyl diversity of the Permian-Triassic Colônia Orozco Local Fauna (Buena Vista Formation) of Uruguay. Revista Brasileira de Paleontologia, 10(3):169-180,

Romer, A.S. 1947. Review of the Labyrinthodontia. Bulletin of the Museum of Comparative Zoology, 99(1):1-368.

Rusconi, C. 1951. Laberintodontes triásicos y pérmicos de Mendoza. Revista del Museo de Historia Natural, Mendoza, 5:33-168.

Santana, R.G. 1992. Tetrápodes fósseis da Formação Sanga do Cabral (Eotriássico do RS). Porto Alegre. Programa de PósGraduação em Geociências, Instituto de Geociências, Universidade Federal do Rio Grande do Sul, Master thesis, 95 p.

Scherer, C.M.; Faccini, U.F. \& Lavina, E.L. 2000. Arcabouço estratigráfico do Mesozóico da Bacia do Paraná. In: M. Holz \& L.F. De Ros (eds.) Geologia do Rio Grande do Sul, UFRGS, p. 335-354.

Schoch, R.R. \& Milner, A.R. 2000. Handbuch der Paläoherpetologie, (Encyclopedia of Paleoherpetology)Stereospondyli, Part 3B. München, Verlag Dr. Friedrich Pfeil, $203 \mathrm{p}$.

Shishkin, M.A. 1994. A Gondwanan rhytidosteid (Amphibia, Temnospondyli) from the Lower Triassic of southern Cisuralia. Paleontological Journal 28:127-143.

Warren, A.A. \& Hutchinson, M.N. 1983. The last labyrinthodont? A new brachyopoid (Amphibia, Temnospondyli) from the Early Jurassic Evergreen Formation of Queensland, Australia. Philosophical Transactions of the Royal Society of London B, 303:1-62.

Warren, A.A. \& Hutchinson, M.N. 1987. The skeleton of a new hornless rhytidosteid (Amphibia, Temnospondyli). Alcheringa, 11:291-302.

Warren, A.A. \& Snell, N. 1991. The postcranial skeleton of Mesozoic 
temnospondyl amphibians: a review. Alcheringa, 15:43-64.

Warren, A.A. \& Turner, S. 2004. The first stem tetrapod from the Lower Carboniferous of Gondwana. Palaeontology, 47(1):151184.

Watson, D.M.S. 1917. A sketch classification of the Pre-Jurassic Tetrapod Vertebrates. Proceedings of the Royal Society of London, B1917:167-186.

Watson, D.M.S. 1919. The structure, evolution and origin of the Amphibia - The "Orders" Rachitomi and Stereospondyli. Phylosophical Transactions B. CCIX-B, 360:1-73.
Watson, D.M.S. 1926. Croonian Lecture. The evolution and origin of Amphibia. Philosophical Transactions of the Royal Society of London, B214:189-257.

Yates, A.M. \& Warren, A.A. 2000. The phylogeny of the 'higher' temnospondyls (Vertebrata: Choanata) and its implications for the monophyly and origins of the Stereospondyls. Zoological Journal of the Linnean Society, 128:77-121.

Zerfass, H.; Lavina, E.L.; Schultz, C.L.; Garcia, A.J.V.; Faccini, U.F. \& Chemale, F.Jr. 2003. Sequence stratigraphy of continental Triassic strata of southernmost Brazil: a contribution to southwestern Gondwana palaeogeography and palaeoclimate. Sedimentary Geology, 161:85-105.

Received in October, 2007; accepted in March, 2008. 